\title{
INDONESIA KITA: Menafsir Ulang Konsep Negara-Bangsa
}

\author{
F A C H R UROZ I*)
}

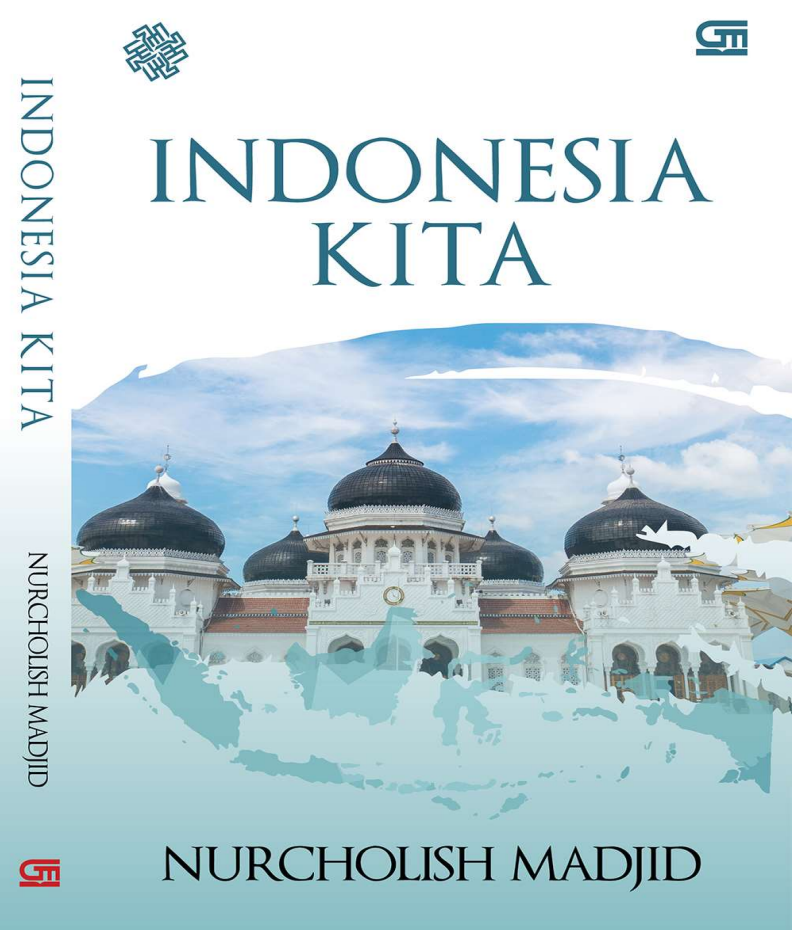

Indonesia Kita (2003; 2004; 2018) merupakan puncak pemikiran Cak Nur (1939-2005)panggilan akrab Nurcholish Madjid-yang lahir dari perenungan mendalam mengenai kenegaraan, keislaman, kemanusiaan, kebudayaan, dan politik dalam bingkai keindonesiaan.

Refleksinya yang mendalam atas situasi mutakhir bangsa ini dengan sangat baik diulas Cak Nur dalam buku ini. Ia memulai pembahasan dengan menggali akar historis bangsa Indonesia, sejak dari nasionalisme klasik di Nusantara hingga situasi saat ini. Berangkat dari perkembangan sejarah tersebut, Cak Nur menyimpulkan bahwa proses menjadi bangsa

\footnotetext{
* Direktur Eksekutif Nurcholish Madjid Society (NCMS), Mahasiswa Pascasarjana STF Driyarkara Jakarta
}

Judul Buku:

Indonesia Kita

Penulis:

Nurcholis Madjid

Penerbit:

Gramedia

Cetakan:

Ketiga, Agustus 2018

Tebal:

xix +192

Indonesia bersifat dinamis, tergantung kepada kita ke mana mau membawanya.

Karena itu, usaha untuk merumuskan kembali makna menjadi bangsa Indonesia selalu relevan. Cak Nur mengajak setiap elemen bangsa ini untuk menelaah kembali hakikat berbangsa dan bernegara, terlebih saat bangsa ini dihadapkan pada masalah langkanya rasa kebersamaan seperti yang mencuat saat ini. Melalui proses ini, ia berharap bangsa ini mampu menemukan sekaligus meneguhkan kembali ikatan kebersamaan yang dulu pernah ditunjukkan para pendiri bangsa sehingga terjadi penyatuan seluruh potensi dan kekuatan yang dimilikinya.

Buku yang ada di hadapan pembaca ini ditulis saat Cak Nur melakukan perjalanan ibadah umroh pada 2003, lalu menyelesaikan penulisannya di tanah air. Jika melihat dari cara Sang Guru Bangsa menulis karya ini ada kesan mendesak bagi Cak Nur untuk menuliskan pemikirannya di bidang kebangsaan dan kenegaraan. Paling tidak itulah yang terekam dari beberapa kali perbincangan saya dengan Omi Komaria Madjid, istri Cak Nur, di berbagai perjumpaan. Kata Omi, ide dan pemikiran Cak Nur yang terurai di dalam Indonesia Kita merupakan refleksi atas situasi Indonesia modern yang dianggapnya sebagai pekerjaan rumah yang 
harus ia selesaikan segera. "Cak Nur ingin sekali menulis mengenai persoalan kenegaraan ini. Seperti ingin menunaikan janjinya," tuturnya. Memang betul, risalah yang ia tulis ini memuat pelajaran dari masa lalu dan serangkaian pandangan praktis bagaimana mengelola negarabangsa yang besar dan beragam ini.

\section{Sosok Pemikir Integratif}

Karya ini menampilkan Cak Nur sebagai sosok pemikir integratif, yang berupaya menyatukan dua keharusan yakni, pertama, tetap sebagai muslim yang loyal dan berkomitmen terhadap ajaran dan nilai-nilai keislaman, dan kedua, menjadi muslim dengan tetap berkomitmen terhadap nilai-nilai kemodernan. Cak Nur meyakini betul bahwa menjadi muslim tidak harus menolak modernitas, atau melepaskan nilai-nilai agama, di sisi lain. Seseorang bisa menjadi muslim yang saleh dan modern sekaligus.

Gagasan ini penting untuk disampaikan kembali ke publik sebab saat ini kita berada di satu era di mana segala sesuatu selalu dipandang secara berlawanan. Kalau Anda seorang muslim yang taat, tak mungkin menjadi modern sekaligus (dalam pengertian sekuler); atau menjadi A tidak mungkin menjelma sebagai B sekaligus. Kita harus memilih di antara dua kutub itu. Pemikiran-pemikiran antagonistik inilah yang ingin ditolak Cak Nur. Kalau para pembaca menelusuri karya-karya Cak Nur, model berpikir integratif seperti ini sangat nampak dalam seluruh karya-karyanya. Boleh dibilang, inilah warisan terpenting Cak Nur yang harus ditumbuhkembangkan di dalam masyarakat muslim agar tidak mudah jatuh pada tendensitendensi antagonistik yang memecah-belah masyarakat ke dalam dua polarisasi ekstrem.

Muhamad Wahyuni Nafis dalam Cak Nur Sang Guru Bangsa: Biografi Pemikiran Prof. Dr. Nurcholish Madjid (2014) menyebut Cak Nur telah memberi sumbangan penting pada integrasi nilainilai keislaman dengan empat komponen penting dalam kehidupan manusia yakni integrasi Islam dan kemanusiaan; integrasi Islam dan politik; integrasi Islam dan komodernan; dan integrasi Islam keindonesiaan. Keempat proses integrasi itu menyatu antara satu dengan yang lainnya dalam satu kesatuan konsep yang bertujuan untuk membangun Indonesia yang modern sekaligus
Islami dan humanis.

Karya ini dengan jelas menunjukkan integrasi nilai-nilai keislaman dengan keempat komponen penting kehidupan umat yang disebut di atas. Nampak di sini Cak Nur sebagai sosok yang tidak ingin menjadi kosmopolit tanpa berjejak kepada keindonesiaan dan keislaman, karena itu ada upaya interpretasi terhadap konsep negara-bangsa dan nasionalisme Indonesia yang berjangkar pada semangat egalitarianisme (teladan Madinah) bisa dipahami secara baik oleh anak-anak bangsa generasi berikutnya.

\section{Bukan Pengakuan, Tapi Penerimaan}

Indonesia Kita lahir di masa transisi bangsa ini menuju demokrasi. Memang, Indonesia sudah lepas dari rezim totaliter Orde Baru, tetapi kebiasaan, tradisi dan sistem yang telah berlangsung lama, masih terus dipraktikkan di berbagai institusi negara dan merambat ke kehidupan sehari-hari warga. Indonesia belum benar-benar bebas dari praktik-praktik kotor korupsi, kolusi, dan nepotisme. Di era transisi ini, ada banyak persoalan muncul sebagai akibat dari keteledoran para elit negeri di era sebelumnya. Konflik-konflik lahir silih berganti. Masyarakat mudah sekali tersulut untuk bertikai lantaran sirnanya semangat gotong royong dan kebersamaan. Di tengah situasi itu, Cak Nur mengingatkan prinsip penting dari ide mengenai Indonesia yakni penerimaan terhadap kemajemukan bangsa, tetapi bukan sekadar memberi pengakuan (recognition) kepada yang berbeda saja, melainkan adanya penerimaan (acceptance) kepada mereka yang berseberangan dalam hal budaya, suku, agama, kebiasaan, dan keyakinan sebagai bagian dari diri kita. Itulah fakta kita sebagai Indonesia yang sesungguhnya.

Sejak era sebelum kemerdekaan, para pendiri bangsa telah menyadari bahwa keberagaman merupakan modal penting bagi Indonesia untuk membangun bangsa ke depan. Juga selama era revolusi di Yogyakarta, misalnya, kita bisa melihat bagaimana para tokoh bangsa lintas etnis dan iman, dari kalangan sipil dan militer, menjalin ikatan kebersamaan dengan apik. Semangat kebersamaan dengan mengesampingkan perbedaan agama, ras, suku, dan bahasa menjadikan Yogyakarta sebagai miniatur Indonesia di tanah Jawa. Para tokoh agama dengan latar pandangan berbeda seperti Ki 
Bagoes Hadikoesoemo (Muhammadiyah), K.H. Wahid Hasjim (Nahdlatul Ulama), Mohammad Natsir (Persatuan Islam), Sayyid Shah Muhammad Al-Jaeni (Ahmadiyah), I.J. Kasimo (Katolik) begitu apik membangun pergaulan dan komunikasi untuk Indonesia yang lebih besar.

Perbedaan pandangan dan keyakinan agama serta pendapat politik tidak membuat mereka saling menjatuhkan, apalagi saling melenyapkan. Perbedaan telah menjadikan mereka lebih kaya dan membuat keyakinan mereka menjadi semakin kuat. Perbedaan tidak menjadi alasan bagi mereka untuk saling mencaci, saling membenci, tidak menghormati dan tidak bergaul sebagai sesama ciptaan Tuhan.

Berbagai literatur sejarah pun menunjukkan bahwa masuknya Islam ke bumi Nusantara lewat cara yang unik dan jenius. Islam yang berkembang di Nusantara merupakan perpaduan antara Islam yang datang dari tanah Arab dengan warna dan nuansa budaya lokal yang sangat kental. Tak ada konflik dan peperangan besar ketika syiar Islam mulai disebarkan ke berbagai pelosok Nusantara. Malah hebatnya lagi, para pendakwah menggunakan media instrumen musik dan budaya lokal dalam menceritakan nilai-nilai penting ajaran Islam agar mudah diterima masyarakat. Pesan Islam pun masuk lewat lantunan gamelam dan kisah pewayangan yang begitu masyhur.

Hal yang sama juga terjadi pada peradabanperadaban lain yang berkembang di Nusantara, seperti pada Hindu, Buddha, Kristen dan Katolik. Ornamen dan simbol-simbol yang digunakan di rumah-rumah ibadah agama-agama itu berbeda jauh dari apa yang biasa digunakan di negeri asalnya. Ada gamelan, gong, atau angklung, misalnya, di gereja, vihara, pura, dan klenteng. Ada pula yang menggunakan bahasa lokal saat melangsungkan ibadah atau kebaktian. Akulturasi budaya (bukan ajaran agama) inilah yang memungkinkan negara-bangsa Indonesia masih berdiri sampai hari ini.

Itulah gagasan utama Cak Nur yang terurai di buku ini bahwa Indonesia adalah negarabangsa yang ditakdirkan menerima keragaman agama, keyakinan, tradisi, bahasa, dan budaya. Karena itu, berulang kali Cak Nur bersyukur dan memuji para pendiri bangsa yang bersepakat menetapkan Pancasila sebagai dasar negara, bukan berdasarkan kepada satu agama, etnis, atau budaya tertentu. Indonesia bukanlah Jawa, Dayak, Sumatera, Sulawesi, Papua, Aceh, Islam, Kristen, Katolik, Hindu, Buddha, Kong Hucu, tetapi merangkum semuanya dalam satu kesatuan negara-bangsa.

Sungguh jenuin memang pendiri bangsa yang menyertakan nilai keberagamaan dalam dasar hukum negara. Boleh dibilang ini pula yang menjadi cikal bakal tercetusnya sila pertama, Ketuhanan Yang Maha Esa. Sila ini menggambarkan fitrah kehidupan beragama di Indonesia yang menjadi landasan nasionalisme di Indonesia. Namun, nilai keberagamaan ini bisa tumbuh dengan sehat, jika ditopang dengan kehidupan agama yang sehat pula.

\section{Menafsir Ulang Konsep Negara-Bangsa}

Sebagai sosok pemikir yang setia menggeluti persoalan bangsanya, bisalah dimengerti mengapa Cak Nur memungkasi karya tulisnya dengan menyusun risalah mengenai kebangsaankenegaraan.

Konsep negara-bangsa merupakan satu persoalan penting yang ia tafsir ulang di karya ini. Kata Cak Nur, "negara-bangsa" adalah suatu gagasan tentang negara yang didirikan untuk seluruh (komunitas) bangsa. Cak Nur mengurai bahwa pengertian "bangsa" ("nation") itu di dalam bahasa Arab itu sering diungkapkan dengan istilah ummah (ummatun, umat), sedang konvergensi seluruh komunitas bangsa ke dalam suatu kesatuan politik dan tatanan hidup bersama disebut "al-Umam al-Muttahidah" (umatumat bersatu).

Uraian ini menurut saya penting diungkap Cak Nur agar ada pemahaman yang benar mengenai konsep negara-bangsa (ummah) yang selama ini kerap disalah-mengerti. Sebagian masyarakat kita langsung menisbatkan kepada umat Islam begitu mendengar istilah ummah atau umat. Kata Cak Nur, merujuk pada tafsir Muhammad Asad, kata ini bermakna komunitas yang tentu saja bersifat umum, dalam arti tidak merujuk hanya kepada umat Islam sebagaimana dipahami sebagian kalangan di Indonesia. Ummah juga berarti bangsa (hal. 35-36). Pengertian berbeda disampaikan Abdullah Yusuf Ali, seorang penafsir al-Quran kelahiran Pakistan yang kerap dirujuk Cak Nur, bahwa kata ummah berarti persaudaraan (fraternity).

Jadi, negara-bangsa adalah tempat 
berhimpun seluruh umat atau warga masyarakat yang didirikan berdasarkan kesepakatan bersama yang menghasilkan hubungan kontraktual dan transaksional terbuka antara pihak-pihak yang mengadakan kesepakatan itu. Negara-bangsa ini dibentuk untuk mewujudkan kemaslahatan bersama al-mashlahat al-âmmah atau al-mashlahat al-mursalah, padanan pengertian general welfare), suatu konsep tentang kebaikan yang meliputi seluruh warga negara tanpa kecuali. Apa yang dikemukakan Cak Nur mengenai konsep di atas menunjukkan bahwa membicarakan kebangsaan Indonesia bisa merujuk kepada bahasa agama, tanpa harus membawa label agama.

Sebagai intelektual yang berkomitmen kepada ajaran agamanya, Cak Nur merujuk dan menghadirkan kembali semangat pembentukan Piagam Madinah yang diprakarsai Nabi Muhammad saw ketika beliau berada di Madinah. Bagi Cak Nur, Piagam Madinah adalah sepadan dengan Pancasila. Karena itu, seorang muslim yang menyadari hal ini, meyakini bahwa Pancasila adalah final sebagai dasar Negara Indonesia.

"Hubungan kontraktual dan transaksional terbuka" yang menjadi ruh dari Piagam Madinah diteladankan dalam Bay'at 'Aqabah yang terjadi antara Nabi Muhammad dan para utusan penduduk kota Yatsrib. Dengan Bay'at di 'Aqabah itu, Nabi memperoleh jaminan keamanan dan keselamatan diri beliau dan kaum beriman nanti di kota Yatsrib setelah hijrah, sedang penduduk kota Yatsrib memperoleh jaminan kepemimpinan Nabi yang adil dan bijaksana untuk menyatukan seluruh penduduk Yatsrib, khususnya antara klan Aws dan klan Khazraj yang bermusuhan. Nabi berjanji akan memerankan diri sebagai pembina konsensus (consensus builder) di Yatsrib, selaku pemersatu dan juru damai antara pihakpihak saling bermusuhan (hal. 37).

Setelah hijrah ke kota Yatsrib, Nabi mengubah nama kota itu menjadi Madinah. Salah satu penjelasan leksikal kata "madinah" berasal dari kata kerja "dâna-yadînu", yang berarti tundukpatuh; yang mengisyaratkan kewajiban manusia untuk tunduk dan patuh kepada kesepakatan dan perjanjian kontraktual yang sah antara manusia dengan Tuhannya dan antara sesamanya (hal. 38).

Singkat kata, Madinah pada mulanya merupakan "negara-kota", seperti halnya polis di Yunani. Tetapi kemudian berkembang menjadi pengertian tentang penyusunan tata pergaulan bersama dalam suatu kesatuan kemasyarakatan tertentu untuk mengembangkan kehidupan yang beradab melalui ketataan kepada konstitusi (hal. 40).

Pembahasan soal negara-bangsa merupakan uraian paling penting dalam buku ini. Tentu saja, sebagaimana diungkapkan di atas, Cak Nur menghendaki lahirnya pemahaman yang benar atas gagasan ini. Cak Nur mengkritik Bung Karno yang mendaulat dirinya sendiri sebagai "Penyambung Lidah Rakyat". Dengan begitu ia telah mengidentikkan dirinya dengan rakyat, lalu cenderung abai terhadap keinginan dan kecenderungan rakyat, terutama demokrasi dan keadilan sosial. Ia juga mengkritik Soeharto yang dianggapnya tidak memahami dengan baik konsep negara-bangsa dan dinilai terlalu mementingkan keseragaman ketimbang keberagaman, dan karena itu menganggap perbedaan sebagai ancaman. Padahal, di bawah kepemimpinan Soeharto, istilah Bhinneka Tunggal Ika, dan juga Pancasila, sering sekali digaungkan di dalam berbagai acara kenegaraan dan penataran. Bahkan sampai menghasilkan gejala verbalisme-yaitu gejala perasaan telah berbuat karena telah sering mengucapkan dan membicarakannya - terhadap Pancasila dan Bhinneka Tunggal Ika. Lantaran saking seringnya membicarakan hal-hal itu, kita lupa mengamalkan nilai-nilai penting dari Pancasila dan Bhinneka Tunggal Ika ini sebagai bagian dari praktik sehari-hari. Banyak orang berbicara, tetapi sedikit sekali yang memberi contoh dan teladan berarti. Boleh dibilang bangsa ini sangat gandrung kepada Pancasila dan Bhinneka Tunggal Ika tetapi pada saat yang sama tetap mempraktikkan nepotisme, melakukan tindak pidana korupsi, menebarkan kebencian, merampas hak-hak orang lain, mengusir kelompok agama lain dari tanah tinggalnya, memberangus keragaman, dan sebagainya.

\section{Nasionalisme Indonesia, Bukan Nasionalisme Religius}

Uraian sejarah yang ditulis Cak Nur memiliki satu misi tertentu yakni memberi pemahaman yang benar tentang sejarah sekaligus memberi bekal bagi generasi setelahnya untuk menjalani sejarah bangsa ke depan. Karena itu, Cak Nur 
menyebut buku ini sebagai risalah, yang secara harfiah bisa dipahami sebagai sebuah pembahasan dengan pesan tertentu.

Meskipun merujuk kepada al-Quran dan sejarah Nabi Muhammad, nasionalisme Indonesia yang dipaparkan Cak Nur bukanlah dimaksudkan sebagai nasionalisme religius, seperti secara latah nampak dalam istilah NKRI Bersyariah, Perda Syariah, dan lain-lain. Cak Nur dengan tegas menolak gagasan itu. Baginya, Indonesia adalah rumah bersama, tempat bernaung berbagai agama, kepercayaan, tradisi, dan budaya. Nasionalisme Indonesia yang ditulis Cak Nur bukan dalam konteks label atau simbol syariah, melainkan paham kebangsaan yang mendasarkan diri pada nilai-nilai atau prinsipprinsip utama agama.

Sebagai bangsa yang dibangun di atas keanekaragaman budaya, suku, dan agama, boleh dibilang Indonesia sukses membangun kebersamaan dan persaudaraan dalam ikatan kebangsaan. Sikap nasionalisme ini pula yang membuat kita yang beraneka ragam ini mau bersatu (Sumpah Pemuda 1928), melepaskan diri dari penjajahan bangsa asing, dan memproklamirkan diri sebagai bangsa yang merdeka.

Namun, nasionalisme Indonesia bukannya tanpa tantangan. Berbagai problem yang bergantian mendera negeri ini telah benar-benar menguji kita sebagai sebuah bangsa. Aneka keterpurukan yang disebabkan berbagai persoalan telah berhasil membuat kita pesimis dan limbung tak tentu arah. Kesenjangan antara yang kaya dan miskin, buruknya kualitas pendidikan, sikap arogan dan serakah para elite penguasa, dan kekerasan yang dilakukan kelompok-kelompok masyarakat yang mengatasnamakan golongan tertentu membuat semangat kebersamaan dan persaudaraan kian memudar.

Padahal untuk menjadi bangsa yang besar, kita memerlukan semua kekuatan dari berbagai elemen untuk bersatu padu dan bekerja sama. Dalam ungkapan Bung Karno yang masyhur: samen bundeling van alle krachten van de natie, pengikatan bersama seluruh kekuatan bangsa (hal. 2).

Indonesia Kita merupakan respons yang diberikan Cak Nur sebagai cendekiawan Muslim terhadap proses demokrasi bangsa ini yang belum kunjung membaik. Runtuhnya rezim otoriter Orde Baru sebetulnya merupakan jalan baru sekaligus kesempatan bagi bangsa Indonesia menentukan sejarahnya sendiri untuk lebih baik lagi.

Memang masih banyak tantangan dan hambatan yang dihadapi bangsa ini dalam berdemokrasi yang dikemukakan Cak Nur dalam warisan terakhirnya ini. Jiwa kerdil yang hanya mementingkan diri sendiri dan kelompoknya masih dominan di bangsa ini, baik di tingkat elite maupun kalangan bawah belumlah hilang dalam penyelenggaraan negara dan praktik sehari-hari bermasyarakat. Hasilnya, nampak adanya kesenjangan yang demikian jauh antara apa yang dicita-citakan oleh para pendiri bangsa dengan kenyataan yang ada saat ini (hal. 101).

Inilah pekerjaan rumah kita bersama. Cak Nur tidak menyebut hanya pekerjaan rumah para elit semata, tetapi seluruh elemen bangsa. Kita yang mengerti benar kekurangmatangan diri sendiri sebagai bangsa. Kita sendiri yang mengetahui aset dan sumber daya yang bisa digunakan untuk menyelesaikan persoalan. Pekerjaan-pekerjaan yang belum terlaksana seperti pembangunan nasional demi maslahat umum dengan keadilan dan kejujuran, merupakan sumber berbagai krisis yang melanda kita sekarang ini. Semua ini harus menjadi prioritas bersama.

\section{"Gizi" untuk Calon Pemimpin Negeri}

Ada korelasi penting antara hadirnya karya ini dengan pemilihan Presiden dan Wakil Presiden 2004 silam. Bisalah dipahami mengapa Cak Nur menulis 10 Platform Membangun Kembali Indonesia di bagian akhir buku ini. Boleh jadi sebagai "gizi" atau "vitamin" yang menjadi satu alternatif untuk menyelesaikan beragam persoalan bangsa. Tentu saja dalam perspektif Cak Nur. Ia tidak berpretensi menjadi satu-satunya penyelesai persoalan dengan 10 Platform yang ia susun itu.

Namun, secara sengaja Cak Nur menginginkan gagasan dan pemikirannya yang tertuang di karya ini menjadi panduan bagi para calon pemimpin nasional yang harus dipahami dan dikuasai dengan baik. Jika dibaca dengan cermat, 10 Platform tersebut merupakan gagasan praktis dan mudah dicerna oleh para calon pemimpin bangsa. Kesepuluh platform ini merupakan "gizi" yang selalu dibawanya 
berkeliling saat menyampaikan visi dan misi sebagai bakal calon presiden.

Cak Nur tidak menyimpan gagasannya ini untuk dirinya sendiri, melainkan dengan senang hati memberikannya kepada siapa pun yang mampu mewujudkannya tanpa keharusan menjadi presiden. Karena itu, saat Susilo Bambang Yudhoyono terpilih menjadi presiden pada 2004, Cak Nur menyampaikan gagasan ini kepadanya. Dan, karena platform ini dapat diakses secara publik, generasi muda pun bisa mempelajari secara cermat visi dan misi Cak Nur tersebut sebagai modal untuk menjadi pemimpin di masa depan untuk Indonesia yang lebih baik.

Jelang Pemilihan Presiden dan Wakil Presiden tahun 2019 nanti, gagasan Cak Nur, soal 10 Platform yang tertuang di buku ini masih tetap relevan. Buku ini layak untuk dibaca dan direnungkan kembali dengan diharapkan bisa membantu memberi alternatif ke mana bangsa ini hendak diarahkan. Inilah dasar dan pertimbangan Nurcholish Madjid Society (NCMS) menerbitkan kembali karya ini.

Bagi Cak Nur, 10 Platform ini dapat menjadi modal dasar membangun kembali bangsa Indonesia dari keterpurukan sekaligus agar mampu berdaya saing dengan bangsa-bangsa lain di dunia.

Tentu saja, Cak Nur tidak berpretensi menjadi satu-satunya pengubah Indonesia. Lewat wacana ini, ia hanya mencoba membuat rintisan, dengan harapan siapa pun yang memberikan keprihatinan yang sama, khususnya dari kalangan generasi penerus, akan mengembangkan dan memperbaikinya, dan melaksanakannya dengan memberi teladan sebaik-baiknya untuk warga masyarakat (hal. 4).

\section{Tantangan Indonesia ke Depan}

Indonesia Kita hari ini memiliki tantangan sangat jelas di depan mata yakni ekstrimisme dan kekerasan atas nama agama, konflik antarsuku dan budaya, dan pemisahan antara ruang publik dan privat. Inilah hadangan Indonesia hari ini, dan di masa depan, jika tidak ditangani secara serius sekarang.

Demokrasi Indonesia hari ini tengah diganggu oleh semakin menguatnya identitas keagamaan yang ikut merangsek ke wilayah politik. Bagi para tokoh agama, fakta ini menjadi pekerjaan rumah yang sangat besar agar segera diantisipasi supaya tidak semakin membesar. Caranya dengan memberi perspektif dan penyadaran kepada segenap umat untuk terus bersikap toleran dan menghargai kelompok lain yang berbeda pandangan dan keyakinan. Prinsipnya adalah bahwa agama tak mungkin ditebarkan dengan rasa benci dan perilaku yang berujung pada kerusakan.

Perjumpaan, dialog tatap muka, dan hidup bertetangga dengan kelompok agama yang berbeda-sebagaimana telah ditunjukkan para pendiri bangsa dan juga dipraktikkan sejak lama di berbagai belahan Nusantara-merupakan kekuatan positif yang mampu menghancurkan rencana-rencana jahat untuk Indonesia tercinta. Semangat tenggang rasa, saling memahami dan saling menghormati satu sama lain merupakan kekuatan dan modal sosial untuk menciptakan masyarakat yang toleran dan harmonis hari ini dan di masa depan. Narasi kebaikan setiap kelompok harus terus dikumandangkan. Para pemuka agama berada di garda terdepan untuk memberikan penjelasan baik ini kepada umat mereka masing-masing.

Akhir kata, uraian Cak Nur yang termaktub di buku ini sangat mudah dipahami dan tidak berbelit-belit. Model uraian seperti ini boleh juga dicontoh kalangan akademik, yang juga dikritik Cak Nur di sini lantaran terlalu mengawang dan menggunakan bahasa rumit yang kurang dipahami masyarakat umum. Inilah satu pesan yang penting diperhatikan, terutama bagi kalangan akademik (juga lembaga riset), bahwa serumit apa pun hasil sebuah penelitian, harus bisa dibahasakan dengan mudah agar bisa diakses oleh generasi yang lebih muda dan belum kaya pengetahuan.

Karya ini sangat penting dibaca oleh generasi muda sebab berisi informasi hasil pembacaan ulang atas sejarah nasionalisme klasik, sejarah Islam dan perjalanan Nabi Muhammad, serta situasi politik Indonesia kontemporer, sehingga bisa mengubah pandangan jalan hidup mereka. Buku ini juga penting dibaca karena menampilkan rekonstruksi sejarah terhadap dimensi-dimensi penting dalam kecakapan-kecakapan sosial kita sehari-hari, yakni keislaman, kemodernan, dan keindonesiaan. Buku ini juga penting dibaca karena ditulis dengan bahasa yang lugas dan ringan sehingga bisa dibaca tanpa harus mengerutkan kening.[] 